\title{
The Effect of Using Songs on Young English Learners' Motivation in Jordan
}

\author{
https://doi.org/10.3991/ijet.v15i24.19311 \\ Manal Hisham Al-Smadi \\ The University of Jordan, Amman, Jordan \\ manalhsmadi@yahoo.com
}

\begin{abstract}
A song is a work of poetry that is typically intended to be sung by human voice many studies have tackled the importance of implementing songs in teaching English as a second language (ESL) showing that they can be very effective in developing student's grammar, pronunciation and vocabulary retention. This paper aims to investigate the effectiveness of using songs on young student's motivation in Jordan. The participants were two different groups from a private school in Jerash. Their motivation was examined with and without implementing music. Analysis of the data using a t- test suggested that using songs in teaching English for young learners was significantly effective in raising their motivation to learn the language. The study also concluded with some implications about the effective use of songs to enhance the effect of these results.
\end{abstract}

Keywords - Motivation, songs, Teaching English language, young English learner.

\section{$1 \quad$ Introduction}

English has become a very important language in the world since it considered to be the language of science, and people realize the importance of learning and teaching English for their kids as well as for themselves. In Jordan English enhances the role of education [5]. It has been introduced to students from kindergarten to university. Though the difference between public and private schools in presenting the language is different, but it still dominates teaching other courses such as science, math, technology and medicine. Because of this importance, children start learning English from kindergartens using different materials and games, and teachers try to imply strategies which make learning English interesting and enjoyable. Learning English starts from this early age to encourage student, to learn the language so that when they grow up, they will be confident to speak and to write.

\subsection{Importance of songs}

Songs are flexible. They are the product of culture, share values, commitment, responsibility, customs, love, traditions, history, and the characteristics of a spoken 
language. They can be used for a number of purposes and there are many reasons why songs can be considered a valuable pedagogical tool. Songs can improve young learners listening, pronunciation and speaking skills as well as their grammar [14]. In addition to this, using songs is considered a type of the active learning strategy which proves to be really effective in teaching foreign languages.

Listening: Despite the different between curricula taught in public and private schools, teachers in both always try to carry out different strategies that will make language acquisition easy for young learners, and to motivate them to learn new vocabulary, pronunciation and grammar. Listening is the principle condition which working with songs relies on. It is represented by receiving and reproducing information. [4] stated that songs have a great effect in the practice of listening, because they are being used in meaningful contexts.

Pronunciation: It is very important for language learner to learn pronunciation of words through music, because most of these words are being sung by native speakers, which means that they are produced with no pronunciation mistakes. These words will be stuck inside their heads, and they will find different accents represented in these songs. [9] stated that it is not important for young language learners to sound like American or British native speakers, but they should be able to communicate in English and music helps them to become familiar with accents and presentation. It offers learners a way to look at contractions, elisions, sounds, words and connected speech.

Grammar: Grammar is an element that could not be ignored in language learning, and it is considered a necessary component of any language teaching program. Since students will be exposed to a great number of rules to learn in English class, it will be very effective if teachers provide students with real authentic condition and try to create a comfortable enjoyable atmosphere, and this is what can be achieved through performing songs. Songs can help students to learn and recall language [7].

Vocabulary: Singing traditional songs, nursery rhymes, and lullabies are essential for babies for their and emotional wellness, educational success [2]. Songs prepare the child's ear, voice and brain for language, and using traditional songs and lullabies can develop the child's ability to present his thoughts into spoken words. Songs teach children How language is constructed, and assist them to acquire it. On the other hand, it is important to use authentic natural language and vocabulary which suit the age they are intended to teach i.e., teaching a language for young learners implies that songs should use action, simple words, and including words of body movements will also be very effective and it will increase their motivation to learn [9].

Importance of motivation: Motivation is considered one of four major elements of learning which are:

- Curriculum

- Readiness

- Intuition

- Motivation [3]

Motivation is essential in learning languages. Educator's planning should use innovative tools that will ensure that the learners will set a task which is challenging 
and realistic to keep them involved up to the end [6]. This paper tackles one of these types which is using songs and investigates its influence on young learner's motivation.

\subsection{Research questions}

1. Does using songs have any effect on motivation of young English learners?

2. Does the gender of young English learners have any effect on their motivation to learn the English language?

\section{$2 \quad$ Literature Review}

It is incontrovertible that teachers of foreign languages should implement all available resources and strategies in classrooms including audio, visual, and audiovisual materials to facilitate acquiring the language. Many studies have shown that playing songs while teaching a language could be of a great benefit to the learner.

[13] examined the way in which songs should be used in teaching English for young learners and he found that using songs as task will help learners to transfer words from these songs into daily use and can increase songs repertoire.

In [15] examined the importance of songs in EFL / ESL classrooms. He based upon his experience as an English teacher more than being based upon previous research and he concluded that appositive attitude and environment enhance learning the language and songs are supportive.

[12] examined the supportive influence of teaching English vocabulary learning and retention and they concluded that using songs had a positive effect on both vocabulary learning and vocabulary retention and these two items were not affected by the gender of participants.

[16] investigated the importance of songs in teaching pronunciation for EFL students. She found that listening to songs creates enthusiasm and challenge for learners. She also noticed that students prefer listening to songs to practice pronunciation because they have found them useful for this purpose. According to [8] we don't learn a language but we acquire it, and songs are great opportunity for students to be implemented in language learning.

[10] investigated the way in which a teacher can motivate his students through using activities such as singing, body movement, dancing etc. She carried out a systematic inquiry to collect the data from the subjects and she concluded that using songs can be used with other activities such as dancing and acting to increase student's motivation and confidence to learn the language.

[6] investigated the importance of using songs in teaching English for young learners in Peru. They used the observation and the questionnaire for two groups of students one with songs and the other without songs. They found that songs had a positive influence on student motivation to learn the language.

[1] examine whether songs, lyrics and poetry can improve English language skills, whether age plays a role in learning via these means. The study also aims to 
investigate the possible factors that could encourage or discourage teachers from using songs and poetry, and whether teaching experience would influence teacher's use of songs as teaching method. The findings revealed that these ways of teaching could help learners acquire foreign language skills and that they are more widely used by less experienced teachers.

[18] Trying to consider the relationship between English songs and learning vocabulary by examining the effectiveness of using English songs in English foreign language classes, to improve learning and recalling the new words as a result of making happy classes and high motivated students. The study indicates that English songs play a magical role in teaching new vocabulary, and they should be used as a type of supplementary materials in teaching. Active vocabulary learning is an activity that is seldom paid any attention in most language classrooms. It is here that songs can be of great help. Numerous words that deal with a particular theme or emotion appear in a song. In some songs particular grammatical features occur with great frequency. Such songs, therefore, can be used as a form of reinforcement for the particular structural item.

[19] the research aims to know the perception of fourth year students towards Use animated songs to improve vocabulary acquisition. The results were based on data collected from school is in Bentulu, Sarawak. It shows that merge motion songs as the intervention strengthens the students' vocabulary leads to have good perceptions and positive reactions of the disciples. It shows that Lesson focus varies from Teacher learner-centered, use of animated songs during the English language lesson, students are motivated and drawn to learn love the English language.

[17] conduct a study to find out the effect of the Google SketchUp application and the need for achievement on students' learning achievements of building interior design. The Google SketchUp application was used in the experimental group, while the PowerPoint Slides were used in the control group. The results show that the Google SketchUp application is more effective than the PowerPoint in the learning of building interior design. For students who have a high need for motivation, using the Google SketchUp application is more effective than using PowerPoint Slides.

\section{$3 \quad$ Methodology}

\subsection{Participants}

This study was conducted in Jerash. In Jordan the mother tongue language is Arabic. However, it is obvious that English is noticeably dominant in some fields of education especially in private schools such as science, technology and math. Education is a dynamic domain which enhances the role of English in Jordan because people are now aware of its special significance worldwide. This may be one of the most important reasons that give rise to the increasing number of private bilingual school where both languages English and Arabic are being taught.

This study was carried out at a private school in Jerash, Jordan. This school, Adam and eve private school. 
The participants were students of third grade. In total, they were 24 students divided into two groups 12 students in a control group and 12 in an experimental group. They were almost at the same age -8 years old. They were 5 males and 7 females in the control and 6 males and 6 females in the experimental group.

\subsection{Materials}

This study uses both qualitative and quantitative approach. The qualitative approach uses observation templates (appendix 1) filled by the research to collect the data about students' attitude and about students' attitude and behaviour toward the lesson with songs and the lesson without songs. These templates were divided into four sections which measure student's motivation, participation, attention and interest.

In the interviews, the questions were almost the same questions asked to students after two different classes one without using songs but using the traditional way of teaching for the control group and the second was after a class with songs performed.

Considering that the participants were children, the questions were asked to students in Arabic then they were translated into English. In the interviews the participants were asked individually and the researcher filled in the questions. These questions were meant to measure interest, importance and motivation of learning English in both traditional and untraditional class environment.

The aim of this test is to find out the differences in students' participation, interest and motivation in the two groups.

\subsection{Procedure}

Interviews were carried out after attending two English classes, a class in which songs were being performed and another without songs. To analyse the collected data in the observation a matrix in Microsoft word was created to compare the observers notes about the two groups performance.

The aim of the descriptive analysis was to generate frequencies and percentages, while observations provide the observers perspectives about students' attitudes and interviews provide students perspectives about using song in class rooms.

\section{$4 \quad$ Results}

The following table shows students perceptions and attitudes about classes in which songs were and were not used for each group. In most questions the difference in students' perceptions can be simply noticed between the two groups. Students in the experimental group liked English class where songs were performed, and their attitudes were positive. 
Table 1. Attitudes of third grade students about their English classes with and without music .

\begin{tabular}{|c|c|c|}
\hline Do you like learning English & Without songs & With songs \\
\hline & Group $A, N=12 \%$ & group $B, N=12 \%$ \\
\hline No, or a little bit & $5(\% 42)$ & $2(\% 17)$ \\
\hline I don't know & $0 \%$ & $1(\% 8)$ \\
\hline I like it & $7(\% 58)$ & $9(\% 75)$ \\
\hline \multicolumn{3}{|c|}{ Do you like participation in English classes? } \\
\hline No, or a little bit & $2(\% 17)$ & $1(\% 8)$ \\
\hline I don't know & $2(\% 17)$ & $0 \%$ \\
\hline I like it & $8(\% 67)$ & $11(\% 92)$ \\
\hline \multicolumn{3}{|c|}{ How did you find this class? } \\
\hline I did not like it & $3(\% 25)$ & $2(\% 17)$ \\
\hline I don't know & $1(\% 8)$ & $0 \%$ \\
\hline I like it & $8(\% 67)$ & $10(\% 83)$ \\
\hline \multicolumn{3}{|c|}{ What is the most interesting thing about English classes? } \\
\hline Reading stories & $2(\% 17)$ & $1(\% 8)$ \\
\hline Writing exercises & $2(\% 17)$ & $2(\% 17)$ \\
\hline Singing songs & $2(\% 17)$ & $4(\% 33)$ \\
\hline Watching videos & $3(\% 25)$ & $3(\% 25)$ \\
\hline Acting sketches and speaking & $3(\% 25)$ & $2(\% 17)$ \\
\hline \multicolumn{3}{|c|}{ Do you think English is important? } \\
\hline No, or a little bit & $1(\% 8)$ & $1(\% 8)$ \\
\hline I don't know & $1(\% 8)$ & $0 \%$ \\
\hline Yes, I do & $10(\% 83)$ & $11(\% 92)$ \\
\hline
\end{tabular}

\subsection{Motivation}

Analysis of observation templates shows that in class with no songs some students did some activities during the class such as talking to each other, taking a look at the English book and some of them started looking at the decorations in their classroom. Some of them were not following the teacher's directions and she had to call them by names to tell them the instructions individually.

On the other hand, in class with songs playing students were happy and they were following the teacher's instruction. students were happy to participate and to work together even without being given instructions to do so. The general environment in the class was positive and students were singing during and after the class.

\subsection{Participation}

In the class with no songs, students participated during the first 15 minutes, and then they started to feel bored. Sometimes the teacher had to repeat the question in order to get the correct answer and to motivate those who were not participating in the class.

In class with songs performed most students liked to participate in the class. It was noticeable that some students who had poor English and rarely participate in class 
were happy to participate some of their answers were not correct but they were happy and singing songs.

\subsection{Interest}

Regarding interest, it was obvious that some students were not interested in the class where any songs were played. Some of them stopped the teacher and asked her about the exercise they were doing. Some of them were writing down answers from the board without trying to find out the way in which the exercise was done. While in class with songs playing students showed a great interest in class. They were following instruction and tried to be chosen by the teacher. They were singing happily even after the song had stopped.

\subsection{Attention}

In classes with no music, students were paying attention in the first 15 minutes, and then they started to be distracted. Some students who were sitting in the back were talking to each other and some of them were drawing. Even some of those who were not talking, they were absent minded. But in classes with music students were paying attention to everything the teacher said. Some of them tried to come up with innovative ideas to relate the song with their lesson and they were happy to listen to the teacher's comments because they want to get ready to listen to the next song. It was clear that students were quieter and paying more attention in classes with songs performed.

\section{Discussion}

To answer the first question which is:

Does using songs have any effect on motivation of young English learners?

The Independent-Sample t-test was used to examine the differences in the average between the experimental group and the control group towards the effect of the using songs on student's motivation toward learning English. Table 2 illustrates this:

Table 2. T-test results to examine the differences in the average between the experimental group and the control regarding the effect of the using songs on student's motivation of towards learning English.

\begin{tabular}{|l|c|c|c|c|c|c|}
\hline \multicolumn{1}{|c|}{ Group } & Number & Means & Std. Deviation & Df & T & Sig. \\
\hline Control group & 12 & 5.66 & 2.10 & \multirow{2}{*}{22} & \multirow{2}{*}{-1.65} & \multirow{2}{*}{0.01} \\
\hline Experimental group & 12 & 7.00 & 1.86 & & & \\
\hline
\end{tabular}

Table 2 shows statistically significant differences at the level of $(\alpha=0.05)$ between the responses of the experimental group and the control group towards the effect of using songs on student's motivation towards learning English. The value of the t-test $(-1.65)$ is a statistically significant value $(0.01)$, indicating differences between the 
two groups and for the benefit of the higher arithmetic mean which is the experimental group, which means that using music in teaching English for young learners had a positive effect on their motivation to learn the language which is the answer to the first question.

To answer the second question which is:

Does the gender of young English learners have any effect on their motivation to learn the English language?

To answer this question, the Independent-Sample t-test was used to examine the differences between males and females average towards the effect of using songs on student's motivation to learn English. Table 3 illustrates this.

Table 3. The results of the t-test show the differences in the average between males and females regarding the effect of using songs on student's motivation to learn English.

\begin{tabular}{|l|c|c|c|c|c|c|}
\hline \multicolumn{1}{|c|}{ Group } & Number & Means & Std. Deviation & df & T & Sig. \\
\cline { 1 - 4 } Male & 12 & 12.00 & 2.28 & 22 & 2.15 & \multirow{2}{*}{0.607} \\
\hline Female & 12 & 11.33 & 2.19 & & & \\
\hline
\end{tabular}

Table 3 shows that there are no statistically significant differences at the level of ( $\alpha$ $=0.05$ ) between the mean responses of males and females with regard to the effect of using songs on student's motivation to learn English. The value of t-test (2.15) and the level of significance (0.607) are non-statistically significant, and this indicates that there is no difference between males and females. This means that there is no difference in motivation between males and females toward learning the English language because of using songs, and this is the answer to the second question.

\section{Conclusion}

The results indicate that using songs had a positive influence on student's motivation. This could be easily noticed through the results of the observation and the interview. There was a noticeable change in student's behaviour and attitude to learn English between classes with no music to the classes with music.

In the descriptive question "What is the most interesting thing about English classes?" the number of students who responded that they prefer music increased in the experimental group. This is because singing songs could be considered more interesting and enjoyable than other activities and the learners can find simple sentence structure and sentence pattern that can become set in his or her mind. It's also because songs can rouse students to sing and interact with action songs.

The results also indicate that there is no significant difference in motivation regarding the gender because both of them experience a positive influence with songs. 


\subsection{Pedagogical implication}

The results of the study show that using music has a great effect on student's motivation. Teachers should take such results into consideration within the lesson plan. They should use different kinds of music in classrooms to improve student's pronunciation, grammar, listening and pronunciation. Songs should be part of our syllabus and textbooks.

Teachers can also use it in EFL teaching because their words can stick in their minds. There should be further research on the type of activity that can be used songs.

\section{$7 \quad$ Acknowledgement}

I acknowledge Dr. Richard Garret for his assistance in carrying out this research and Dr. Rajai Al-Khanji for his guidance and support.

\section{References}

[1] Aguirre, D. Bustinza, D \& Garvich, M. (2016). Influence of songs in primary school student's motivation for learning English in Lima, Peru'. English Language Teaching, 9(2). https://doi.org/10.5539/elt.v9n2p178

[2] Blythe, S. (2011). The genius of natural childhood: Secrets of thriving children. Gloucestershire: Hawthorn Press.

[3] Bruner, J. S., 1977 [1st ed. 1960], The process of education, Cambridge, MA: Harvard University Press.

[4] Claerr, T. \& Gargan, R. (1984). 'The role of songs in the foreign language classroom'. OMLTA Journal, 28:28-32.

[5] Drbseh,M \& Hasan, M. (2013).' The spread of English language in Jordan'. International Journal of Scientific and Research Publications, 3(9): 2013

[6] Engh, D. (2013). 'Why use music in English language learning? A survey of the literature'. English Language Teaching, 6(2):113-127. https://doi.org/10.5539/elt.v6n2p113

[7] Hassani, M, Rahmani, R \& Fard, J. (2014). 'The effect of songs on EFL learner's grammar'. International Journal of Language Learning and Applied Linguistics World, 5(2): 233-243.

[8] Kanonidou, E. \& Papachristou,V. (2018). The Use of Songs, Lyrics and Poetry in EFL Teaching and in SLA: Students' and Teachers' Views Conference Paper, May 2018.

[9] Kioko, A. (2015). Why schools should teach young learners in home language. Retrieved from https://www.britishcouncil.org/voices-magazine/why-schools-should-teach-younglearners-home-language

[10] Krashen, S. (1983). Principles and practices in second language acquisition. Oxford: Pergamon Press.

[11] Kuśnierek,A. (2016). 'The role of music and songs in teaching English vocabulary to student's.World Scientific News,43 (1): 1-55.

[12] Madani, D \& Mahboobeh, M. (2016). 'The effect of songs on vocabulary retention of preschool young English language learners. International Journal of Research Studies in Language Learning, 6 (3): 63-72. https://doi.org/10.5861/ijrsll.2016.1562 
[13] Millington, N. (2011). Using songs effectively to teach English to young learners. Language Education in Asia, 2(1): 134-141. https://doi.org/10.5746/leia/11/v2/i1/a11/milli ngton.

[14] Murphey, T. (1992). The discourse of pop songs. Tesol Quarterly, 26(4):770-774. https:// doi.org/10.2307/3586887

[15] Schoepp, K. (2001). "Reasons for using songs in the ESL/EFL classroom." The internet TESL journal 7(2):1-4.

[16] Ulate, N. (2007) 'Using Songs to Improve EFL Student's Pronunciation'. Letras,2 (44):128-192.

[17] Sitanggang, N., Adelinna Luthan, P. \& Dwiyanto, F. (2020). The Effect of Google SketchUp and Need for Achievement on the Students' Learning Achievement of Building Interior Design. International Journal of Emerging Technologies in Learning (iJET) (15): 4-19. https://doi.org/10.3991/ijet.v15i15.12471

[18] Malekian, S. (2016). The Relationship between English Songs and Learning Vocabulary. International Journal of African and Asian Studies, Vol20.

[19] MdYunus, M. (2019) Pupils' Perceptions on the Use of Action Songs in Teaching and Learning Vocabulary. International Journal of Innovative Research and Creative Technology, 4 (6)

\section{Author}

Manal Hisham Al-Smadi Ph.D. Candidate, Department of English language and literature. The University of Jordan. Amman, Jordan. Linguistics. Email: manalhsmadi@yahoo.com.

Article submitted 2020-10-04. Resubmitted 2020-10-29. Final acceptance 2020-10-30. Final version published as submitted by the authors. 


\section{Appendix 1}

The song included with the third-grade curriculum to explain (the use of must and mustn't) rule. Action pack, Unit 10 page 41:

- On a bus trip, you must sit down. You mustn't stand up

- And you mustn't shout.

- On a school trip, you mustn't forget your lunch and water,

- and a hat for your head.

- Look for animals on a mountain walk.

- Listen to the guide and you mustn't talk.

\section{Appendix 2}

Table 4. Observer's notes

\begin{tabular}{|l|l|}
\hline \multicolumn{1}{|c|}{ Behavior } & \multicolumn{1}{c|}{ Notes } \\
\hline Motivation & \\
\hline Participation & \\
\hline Attention & \\
\hline Interest & \\
\hline
\end{tabular}

\section{Appendix 3}

Interview questions

Tick the correct answer.

\section{General information}

How old are you?

1. Do you like learning English?
(a) Nothing
(b) A little bit
(c) I don't know
(d) I like it
(e) I like it a lot

2. Do you like participation in English Classes?
(a) Nothing
(b) A little bit
(c) I don't know
(d) I like it
(e) I like it a lot

3. How did you find today's class?

(a) I didn't like it at all 

(b) I didn't like it
(c) I don't know
(d) I liked it
(e) I liked it a lot

4. What encourages you to learn English?
(a) Reading stories
(b) Writing exercises
(c) Singing songs
(d) Watching videos
(e) Acting sketches and speaking

5. Do you think it is important to learn English?
(a) No, I don't.
(b) Not very much
(c) I don't know.
(d) Yes, I do
(e) Yes, it is very important. 